\title{
POESIA SEGUNDO PAUL ZUMTHOR NA CANÇÃO METAL CONTRA AS NUVENS, DE RENATO RUSSO
}

\author{
Poetry according to Paul Zumthor at the song Metal contra as nuvens, by \\ Renato Russo
}

\section{Elisângela Maria Ozório}

D http://orcid.org/0000-0001-5839-942x

Secretaria da Educação do Estado de São Paulo, Escola Estadual Professora Adalgisa Cavezzale de Campos, Palmital, SP, Brasil. 19970-000 - e034162a@educacao.sp.gov.br

Resumo: Paul Zumthor $(1997 ; 2005 ; 2007)$ apresenta teorias e críticas acerca da poesia presente na canção. Para isso, o crítico vale-se do estudo sobre a poesia oral e passa a reconhecer que toda poesia possui, pelo menos, duas vozes que se conectam: a voz do eu poético e a voz do intérprete que executa a canção. A voz do intérprete incorpora a voz do eu poético, o que facilita a recepção da mensagem poética, já que tal prática precisa da performance que está contida na canção. Portanto, a performance figura como uma das ideias centrais do teórico, assim como ele a diferencia da pura recepção e assim como também define o que é canção. $\mathrm{O}$ artigo Poesia segundo Paul Zumthor na canção Metal contra as nuvens, de Renato Russo se dispõe a pensar a canção poética, usando a letra músico-poética Metal contra as nuvens (1991), do compositor e poeta Renato Russo. Além do mais, antes de adentrar nas proposições de Paul Zumthor, o artigo conta com os estudos de Octavio Paz (1982) para aclarar o que são a poesia e a palavra poética.

Palavras-chave: Paul Zumthor. Canção. Poesia.

\begin{abstract}
Paul Zumthor (1997; 2005; 2007) presents theories and criticisms about poetry present in the song. For this, the critic counts with estudies about oral poetry and he starts to recognize that all poetry has, at least, two voices that connect: the voice of the poetical self and the voice of the singer who performs the song. The voice of the singer embodies of the poetical self, which facilitates the reception of the poetic message, as such practice needs the performance contained in the song. Then, the performance has one of the central ideas of the theorist, just as it as differentiates it from the pure reception and also defines what is a song. The article Poetry according to Paul Zumthor at the song Metal contra as nuvens, by Renato Russo sets out to poetic song, using the musician-poetic lyrics Metal contra as nuvens (1991), by the composer and poet Renato Russo. Moreover, before entering Paul Zumthor, the article counts on Octavio Paz (1982) to clarify what the poetry and the poetic word are.
\end{abstract}


Keywords: Paul Zumthor. Song. Poetry.

\section{Canção: alguns apontamentos sobre poesia}

Paul Zumthor (1997) apresenta um trabalho de pesquisa sobre a poesia oral e os meandros que ela desenvolve tanto nas sociedades primitivas, quanto nas sociedades modernas, entendendo aqui a modernidade como o tempo atual. Para o crítico, a poesia oral encontra-se no germe de uma palavra praticada e ouvida que apresenta uma recepção que atinge o corpo físico-emocional do ouvinte (ZUMTHOR, 1997). Isto é, a palavra da poesia que se localiza na oralidade possui uma capacidade ímpar de ser recebida pelo ouvinte, muitas vezes, essa forma de recepção tende a ser mais profunda do que uma palavra poética escrita, cuja oralidade está aparentemente adormecida pela também aparente ausência de uma voz sonora. Conforme Paul Zumthor (2007), a profundidade da poesia que se dá pela via da canção consiste na recepção exata da palavra poética pela voz oralizada, ou seja, a recepção da mensagem poética através da voz que canta atinge mais rápida e momentaneamente o corpo físico e sensório do ouvinte que desperta as emoções e as reflexões em concomitância. A mensagem poética pela canção apresenta, portanto, uma recepção fluida.

Paul Zumthor (2005) ainda explana que a poesia escrita também possui uma voz que transmite a mensagem de forma plena e profunda, mas diferente na velocidade e na recepção, posto que a voz é um elemento mais rápido na comunicação do que a escrita que depende, primordialmente, da habilidade leitora, enquanto a canção depende da execução. Outro aspecto importante a ressaltar sobre Zumthor (2007) consiste na diferenciação dos conceitos recepção e performance. Conforme o crítico, a recepção pura de uma mensagem não acontece de maneira concomitante com a sua execução, porque a recepção ocorre em um dado momento histórico, tornando-se um fato da lógica (ZUMTHOR, 2007). Já a performance, não possui o instante histórico e lógico, porque a mensagem é sentida na e durante a sua execução: "A performance é a ação complexa pela qual uma mensagem poética é simultaneamente, aqui e agora, transmitida e percebida" (ZUMTHOR, 1997, p. 33, grifo do autor). A canção, por sua vez, enquadra-se na performance e não na recepção pura e literal do que se comunica. No entanto, em termos de compreensão da proposta do artigo, quando este utilizar o vocábulo "recepção", fará referência à performance e não à recepção pura, acompanhando a conceituação de Paul Zumthor (1997; 2007), bem como discorrerá sobre a performance num segundo momento.

Diante das diferenciações e dos conceitos, o presente artigo deseja abrir uma breve reflexão sobre a poesia presente na música Metal contra as nuvens (1991), do músico, compositor e poeta Renato Russo, a partir das ideias de Paul Zumthor (1997; 2005; 2007) sobre a poesia, a voz e a performance, afinal a poesia, a voz e a performance compõem a canção.

Antes, contudo, de adentrarmos nas proposições de Paul Zumthor (1997; 2005; 2007), é interessante lembrar que a poesia se constitui de uma linguagem própria, cuja representação se dá por meio da palavra. A representação da palavra poética cria mundos reais e possíveis para serem experimentados e vivenciados pelo indivíduo que a lê, pratica, canta; pois, nela, se encontra uma espécie de alteridade que complementa o ser. De acordo com Octavio Paz (1982),

Anu. Lit., Florianópolis, v. 25, n. 2, p. 15-27, 2020. ISSNe 2175-7917 
a poesia corresponde a uma vivência do outro, mas que, finalmente, é uma vivência do próprio indivíduo, já que ele passa a ser outro e, sendo outro, experimenta novos mundos, novas sensações, novas crenças, novos conhecimentos, novas emoções:

A poesia é conhecimento, salvação, poder, abandono. Operação capaz de transformar o mundo, a atividade poética é revolucionária por natureza; exercício espiritual, é um método de libertação interior. A poesia revela este mundo; cria outro. [...] Súplica ao vazio, diálogo com a ausência, é alimentada pelo tédio, pela angústia e pelo desespero (PAZ, 1982, p. 15).

Octavio Paz (1982) fornece uma explicação poética da própria poesia e do poema. No fragmento exposto, fica claro que a poesia se constitui de representações de mundos que são vividos pela emoção e despertam conhecimentos pela razão. A linguagem da poesia existe porque há um incômodo frente ao mundo da realidade, uma insatisfação, que leva às recriações ora para entender este mundo, ora para fugir deste mesmo mundo, ora para recriar novas possibilidades de ser neste mundo. A canção Metal contra as nuvens (1991) mostra um eu poético que expõe a insatisfação com o mundo em que vive e busca acreditar que haverá um outro tempo, em que o mundo não será mais imperfeito, e sim perfeito, onde suas histórias serão lembranças de conquistas e recheadas de prazeres, como percebemos no canto final: "E nossa estória não estará pelo avesso / Assim, sem final feliz. / Teremos coisas bonitas para contar" (RUSSO, 1991). A canção final abre o espaço do mundo da utopia, a ideia de que há um espaço e um tempo perfeitos, em que as pessoas são felizes e não há desigualdade entre os homens. A ideia da utopia na obra de Renato Russo muito lembra as proposições de Thomas More (2015), no livro A Utopia, em que há a descrição de uma sociedade edificada na coletividade como forma de se propagar a paz e a bondade e conquista, assim, a cumplicidade. A sociedade "coletivizada" de Thomas More (2015) entende que o ser humano se torna bom se convive e vive a bondade, por causa disso, o bem-estar individual só é alcançado com o bem-estar de todos os habitantes. Logicamente, a descrição da Utopia apresenta muitos pontos a serem debatidos incansavelmente, contudo, a grosso modo, interessa-nos saber que, em Renato Russo, com uma visão geral de sua obra, a utopia consiste em um tempo e um espaço perfeitos, em que o ser humano atinge sua perfeição quando não está mais solitário e seu mundo não condiz com a prática do individualismo, da ambição e da maldade. Metal contra as nuvens (1991) representa tanto o mundo da utopia, como vimos com o trecho acima, quando o eu poético lança para o futuro a certeza de que a nossa história não será contada somente pelos atos hediondos, e sim "pelas coisas bonitas" (RUSSO, 1991), sendo que as "coisas bonitas" (RUSSO, 1991) serão o alicerce para o tempo da utopia: “Apenas começamos" (RUSSO, 1991).

Por outro lado, a canção lança-se mais à representação da imagem da distopia, em que se recria a sociedade em decadência: o desejo de dominar, a roubo, o descaso e a estupidez:

III

É a verdade o que assombra,

O descaso o que condena,

A estupidez o que destrói. 
Eu vejo tudo que se foi

E o que não existe mais.

Tenho os sentidos já dormentes,

O corpo quer, a alma entende.

Esta é a terra-de-ninguém

E sei que devo resistir-

Eu quero a espada em minhas mãos. (RUSSO, 1991).

Metal contra as nuvens (1991) organiza-se em três canções, enumeradas com algarismos romanos, o que alonga a música para onze minutos de execução. Cada canto apresenta duas facetas que convivem na percepção do eu poético: um real distópico e um sonho utópico. No real, encontram-se todas as maldades humanas, sendo que ele ocupa grande parte do discurso do eu poético; enquanto no sonho, com menos expressão em sua fala, localiza-se a esperança de um tempo e um espaço utópicos. A questão da utopia e da distopia em Renato Russo permeia sua obra cancional, em que não há somente imagens contrárias, e sim imagens em constante diálogo, como dizia Russell Jacoby (2007), em outro contexto e sem ligação com Renato Russo, sobre as ideias utopia versus distopia: elas não se opõem, elas se complementam.

O desgosto do eu poético mostra que a poesia consiste numa salvação de si mesmo, porque, ao representar o mundo real ("verdade", “descaso", “estupidez”, "terra-de-ninguém”), recria a ilusão da resistência, da luta e da possível vitória: "E sei que devo resistir -/ Eu quero a espada em minhas mãos" (RUSSO, 1991). A metáfora da espada como a imagem da luta remete à batalha corpo a corpo, que não é típica na atualidade, quando os armamentos bélicos se resumem aos ataques à distância, com pólvora e produtos químicos. No entanto, não é a uma guerra moderna a que se destina o eu poético, mas a uma batalha entre o nós e os outros, um nós coletivo, social e, de preferência brasileiro comum - o brasileiro que trabalha, paga impostos, cuida da família -, e os outros vistos como indivíduos egoístas, como a classe política ou elitizada, que não se preocupa com o outro, porquanto deseja tudo para si, deseja dominar e ter poder sobre o outro: "Não sou escravo de ninguém / Ninguém senhor do meu domínio" (RUSSO, 1991). O início da canção aponta a diferenciação entre o eu e o outro, sendo o outro aquele que busca o domínio e o eu aquele que percebe essa busca e a rejeita. Verifica-se que, no início da canção, o eu poético ainda se vê como um ser individual, mantendo a estrofe na primeira pessoa: "Sei o que devo defender / E por valor eu tenho / E temo o que agora se desfaz" (RUSSO, 1991). O eu poético sugere ser um homem comum que tem crenças e conhecimentos para não ser uma massa dominada.

A posição do eu poético individualizado cede para o eu poético coletivo na segunda estrofe, ao cantar "Viajamos sete léguas / Por entre abismos e florestas" (RUSSO, 1991), uma vez que a primeira pessoa do singular agora surge como a primeira pessoa do plural. Todavia, há oscilação entre o eu poético individualizado e o eu poético coletivo na canção, porque ele altera o canto entre a primeira pessoa do singular e a do plural. Talvez isso aconteça quando o individual precisa se destacar ao manter a declaração de que "Ninguém senhor do meu domínio" (RUSSO, 1991), mesmo que ele se identifique com aqueles que lutam por uma vida melhor: 
“Apenas começamos” (RUSSO, 1991).

A canção Metal contra as nuvens fora lançada em 1991, em meio às crises econômicopolíticas da gestão Collor, tendo o trabalho gráfico do álbum, com título $V$ (1991), e a instrumentação remetidas à Idade Média, como se o protesto afirmasse que o país vivia sua era medieval, uma vez que não avançava em nenhum setor. A ideia de Idade Média acontece em metáforas como o "sopro do dragão" (RUSSO, 1991), cuja imagem nos remete às crenças sobre a presença de dragões que devastavam plantações ou viviam nos mares, e "Vou guardar o meu tesouro / Caso você esteja mentindo" (RUSSO, 1991), outra imagem que nos lembra a riqueza e o poder econômico tanto na Idade Média, quanto na Idade Moderna. A insinuação sobre a Idade Média começa na música de entrada do álbum, Love Song (1991), uma regravação de uma cantiga trovadoresca de Nuno Fernandes Torneol (século XIII).

Metal contra as nuvens (1991) aparece recheada de elementos medievais para construir uma ideia de batalha medieval em uma época moderna: "Perdi a minha sela e a minha espada/ Perdi o meu castelo e minha princesa" (RUSSO, 1991). Daí a espada simbolizar a luta e a resistência a um real distópico, em que o país é governado por egoístas que fazem o que desejam, onde a "a virtude [está] em outras mãos" (RUSSO, 1991). Retornando a proposta de Octavio Paz (1982), observamos que a poética da canção trabalha como uma salvação e uma transformação a se concretizar no futuro: "Temos muito ainda por fazer" (RUSSO, 1991). O eu poético vê sua salvação na criação de outro mundo, onde pessoas transformadas pela virtude serão livres e felizes: "O que venho encontrar / É a virtude em outras mãos" (RUSSO, 1991). Além disso, o grito de enfrentamento do eu poético configura-se em uma reação ao desespero e à angústia, pois, ao acreditar em novos tempo e espaço, tais emoções são aplacadas pela esperança: “Tudo passa, tudo passará” (RUSSO, 1991).

Metal contra as nuvens (1991), desse modo, surge como uma canção de protesto e de resistência, em que as palavras cantadas tornam-se as palavras poéticas. Isso acontece porque, como pensado inicialmente com Octavio Paz (1982), a linguagem da poesia é uma linguagem de representação livre, que pode e transita livremente por todas as artes, não sendo exclusiva da literatura. Retomando à reflexão inicial do artigo sobre a poesia, Décio Pignatari (1981) afirma que a poesia não pertence unicamente à arte da literatura, porque ela se edifica em uma palavra capaz de construir o outro: "A poesia parece estar mais do lado da música e das artes plásticas e visuais do que da literatura. Ezra Pound acha que ela não pertence à literatura e Paulo Prado vai mais longe: declara que a literatura e a filosofia são as duas maiores inimigas da poesia" (PIGNATARI, 1981, p. 01).

Décio Pignatari (1981), poeta e crítico literário, expressa que a poesia devia ser considerada como uma arte em separado, posto que sua linguagem é capaz de representar qualquer coisa, desde um momento do dia, até emoções profundas e complexas. A poesia desperta emoções e conhecimentos, leva o leitor a entender a si e o mundo a sua volta. Por causa disso, explicar a poesia pela via da filosofia implica a sua morte, ao passo que a confinar na literatura também causa sua morte. A palavra da poesia deve ser livre, porque é essa liberdade que a permite ser capaz de instigar emoções e conhecimentos no instante em que é lida. 
A afirmação de Décio Pignatari (1981) acaba por trazer a problemática da oralidade e da escrita como formas de criação da poesia, afinal a arte poética existe desde os primeiros homens, ainda nas cavernas, nas primeiras tribos, dançando em volta do fogo. A presença da voz que canta a voz do eu poético torna-se indispensável para as poesias primitivas, o que, de maneira estranha, liga-se ao canto produzido por Renato Russo, afinal sua poética vincula-se à voz do intérprete que incorpora a mensagem da poesia, assim como faziam os povos primitivos. Dessa maneira, lembramos que Segismundo Spina (2002) explica que a poesia primitiva, executada pelos primeiros povos e elaborada na oralidade, tinha, pelo menos, duas funções, a de reviver o cotidiano e a de recriar as paixões:

Ao lado de uma poesia tradicional, de interesse coletivo, intimamente ligada aos rituais mágico-religiosos da comunidade, pratica-se uma poesia circunstancial, que versa os temas mais variados, sobretudo profanos, de amor, de guerra, recordações de fatos da vida diária, de sátira aos viajantes estrangeiros. A poesia no seu estágio primitivo não é, portanto, exclusivamente ritual. (SPINA, 2002, p. 15).

A poesia primitiva tratava-se de diversos assuntos e, ao contrário do que muitos pensam, essas palavras não representavam e não eram somente praticadas com interesse religioso. Elas também versavam sobre assuntos diversos: como o dia do trabalho, fatos engraçados e o amor. A poesia primitiva cantava sobre o mundo primitivo e tudo contido nele. Na obra cancional de Renato Russo, há a existência das temáticas do amor, do trabalho e das relações sociais, sendo que, na canção Metal contra as nuvens (1991), ainda que representativa da sociedade moderna, nota-se a temática das relações sociais por meio da identificação de uma grande tribo: "Mas a minha terra é a terra que é minha / E sempre será a minha terra" (RUSSO, 1991). A certeza de que o seu espaço é o espaço de toda uma sociedade leva o eu poético a defendê-la sob a ótica do privado, do pertencimento, da identidade com o lugar em que vive, mesmo que este lugar seja recriado com a "fome e destruição" (RUSSO, 1991). A identificação com o lugar retoma a poesia primitiva, em que se cantava o espaço em que o homem vivia.

Desse modo, entende-se que Paul Zumthor (2005) está um pouco próximo do que dizia Segismundo Spina (2002) sobre as primeiras poesias, em que a voz do intérprete presentifica o objeto poético, transformando-o em objeto sensível. Para Zumthor (2005), a voz da poesia consegue perfurar a carcaça humana e atingir o leitor de tal maneira que o que está sendo lido passa a ser o seu mundo também. Logo a poesia primitiva seria o exemplo, para nós, de tal condição, porque a voz de quem canta se faz matéria audível, depositando-se nos ouvidos do ouvinte que passa a viver a mensagem da canção:

A voz tem sua duração própria. Se eu escuto cantar durante três minutos, esses três minutos são vividos por mim numa intensidade que emana da presença do cantor, da materialidade de sua voz, atingindo meus sentidos de tal maneira que o efeito temporal se acha mais ou menos atenuado (ZUMTHOR, 2005, p. $82)$.

Diante da exposição de Zumthor (2005), compreendemos que a poesia possui, na verdade 
duas vozes, interconectadas, sendo que a oralidade ou a escrita podem atenuar ou enfatizar um dos lados. A voz em Paul Zumthor (2005) refere-se a dois fatos: o primeiro uma voz existente na própria poesia e demarcada pelo eu poético; o outro fato consiste em uma voz que canta, a voz do intérprete, uma voz que lê e incorpora a voz do eu poético. No caso da canção, as duas vozes não são sinônimas, mas interagem e constroem toda uma poesia formada pela voz:

Na voz estão presentes de modo real pulsões psíquicas, energias fisiológicas, modulações de existência pessoal. Gostaria de dizer que a voz reflete de maneira imediata uma certa atitude do homem para com ele mesmo, para com os outros, para com sua consciência e sua palavra: atitude percebida pelos ouvintes de modo empírico, global, a maior parte do tempo sem o menor começo (nem mesmo possibilidade) e análise. Por este meio, esta transmissão vocal constitui um fenômeno essencialmente diferente da transmissão escrita, da percepção mediatizada pela leitura (ZUMTHOR, 2005, p. 117).

Nas palavras do crítico, a voz apresenta uma reação do corpo humano tanto para quem fala, quanto para quem ouve; tal reação não passa despercebida ou ignorada, pois é impossível não se atentar para a voz do outro ou de si mesmo. Desse modo, a voz transmite a mensagem sem intermédios, de maneira direta e rápida, sem muitas divagações ou à espera de uma análise. Uma vez dito, dito está - permitindo-me aqui o uso de uma expressão do senso comum. Diante disso, a canção surge com duas vozes: a voz do eu poético e a voz do intérprete que dá à voz do eu poético a transmissão direta da mensagem, sem esperar qualquer alteração no seu conteúdo.

Paul Zumthor (2007), em outro contexto, acrescenta que a gravação da canção acaba por atenuar a transmissão da mensagem pela voz do intérprete, uma vez que a voz para ser gravada pode não ser imediata, espontânea, como acontecia, nos tempos remotos com a poesia primitiva, cuja mensagem poética dependia da voz do intérprete no momento da execução. Por outro lado, temos conhecimento de algumas obras poéticas da música graças à gravação, como o que ocorre com Metal contra as nuvens (1991). Assim, na referida canção, percebemos claramente que a voz do eu poético depende da voz do intérprete. Por exemplo, as nuances da voz do intérprete, Renato Russo, acentuam a mensagem transmitida: no primeiro canto, temos uma voz mais suave, com poucas variações no tom e na altura, enquanto no canto dois, a voz ganha tons menos melódicos, mais rústicos, próximo da ranhura, do grito, da rebeldia. Não se deve esquecer que a variação melódica tem relação direta com a variação da harmonia instrumental, outro tipo de análise seria necessário, sobretudo de uma análise musical, que não é priorizada neste artigo e que, portanto, não se debruçará sobre este assunto.

A variação da voz do intérprete contribui para a construção metafórica da mensagem poética, pois ao ouvir a voz "calma" em "Não sou escravo de ninguém / Ninguém senhor do meu domínio" (RUSSO, 1991), é possível sentir segurança e tranquilidade nas certezas do eu poético; todavia, ao ouvir "Quase acreditei na sua promessa / E o que vejo é fome e destruição" (RUSSO, 1991), a voz surge como um grito, uma ranhura, que permite a percepção da decepção e da negação do outro que é caracterizado pelo egoísmo. Os exemplos citados conferem à voz do intérprete um elemento da poesia, porquanto a junção entre as duas vozes, a do eu poético e 
a do intérprete, ajuda a compor a metáfora da canção, posto que o ouvinte não passará incólume pela voz do intérprete, já que, como afirmava Paul Zumthor (2005) sobre a voz na poesia: “a voz reflete de maneira imediata uma certa atitude do homem para com ele mesmo, para com os outros, para com sua consciência e sua palavra" (ZUMTHOR, 2005, p. 117).

Em suma, quando o crítico fala que a voz do cantor trabalha como emanação intensa do conteúdo poético, vemos que a poesia oral usa enfaticamente o recurso da voz, porque a poesia oral existe com base na fala, não na escrita. Entretanto toda poesia, escrita ou oral, toda ela, possui uma voz, a voz do eu poético que se comunica, que representa a mensagem da poesia. A voz do eu poético não se iguala à voz do cantor, apesar de viverem ligadas na canção, pois a voz do eu poético pode usar a voz vocalizada do intérprete.

A poesia que se processa na e pela voz sonora, do aparelho fonador, pensando a partir de Paul Zumthor (2005), compreende um elemento de criação que permite que a palavra poética, dependente da voz do eu poético, seja recebida simultaneamente. À vista disso, quando Renato Russo canta Metal contra as nuvens (1991), a voz poética é incorporada pela voz do intérprete, o que torna a mensagem mais facilmente vivida e experimentada.

Sou metal - raio, relâmpago e trovão.

Sou metal, eu sou o ouro em seu brasão.

Sou metal: me sabe o sopro do dragão. (RUSSO, 1991).

Como o metal que é uma substância ou um elemento duradouro e de elevada dureza, tendo boa condução térmica e elétrica, como o fenômeno natural que envolve o raio, o eu poético incorpora as mesmas características do metal, "Sou metal” (RUSSO, 1991), definindose como um elemento quase inabalável, porquanto apresenta durabilidade e dureza, o que remete à ideia de que o eu poético assume a postura da eternidade e da perenidade e não se abala, nem teme o dragão: "me sabe o sopro do dragão" (RUSSO, 1991). Tão forte como o metal e o raio, o eu poético que enfrenta o dragão instala-se no brasão que representa as posses materiais do outro, "eu sou o ouro em seu brasão" (RUSSO, 1991). A voz do cantor, convidativa e compartilhada, permite que a voz do eu poético seja a voz também do ouvinte, pois, quando a canção entra em execução, não existe tão-somente o cantor, mas os cantores que entoam os versos e compartilham da experiência e da força que o eu poético acredita possuir.

\section{A performance de acordo com Paul Zumthor}

Duas características da música roqueira, na qual está inserido Renato Russo, são a letra convidativa e compartilhada e o tom de revolta e de resistência. Ou seja, a letra de música do rock pende para uma melodia que convida o ouvinte a não só ouvir, mas também a cantar e assumir o vocal como se fosse o próprio intérprete. Por causa disso, o convite desta letra promove uma espécie de canto compartilhado, porque ouvinte e intérprete partilham da execução da música, ao mesmo tempo, comungam e experimentam a mensagem contida nela. Na produção de Renato Russo, as letras das canções são convidativas a compartilhar tanto a execução quanto a experiência da mensagem poética. 
Ademais, as composições escritas do rock pendem para uma representação da sociedade em declínio, com guerras, fome, desigualdades sociais; outras vezes, tratam de assuntos profanos, como o sexo e a paixão; outras ainda, as emoções tristes, como a sensação de solidão. As letras partem sempre de um texto simples e acessível para que o ouvinte possa participar do canto. Há que se ressaltar que a ideia de simples pensada aqui não coaduna com a vulgarização ou com letras pobres, que nada representam.

Com relação à característica de revolta e de resistência, deparamos com Paul Zumthor (2005) que afirma que o rock corresponde a uma poesia primitiva, de primórdios, cuja voz (do eu poético ou da canção) parece uma rocha em estado bruto, esperando pela lapidação:

O rock não cessou ainda de produzir seus frutos, de gerar movimentos novos, movimentos do corpo, movimentos do espírito. O rock and roll se inscreve na linha mais direta e mais antiga da poesia vocal de contestação, de protesto, de revolta, de violência que drena toda a história da humanidade. No começo dos anos 60, eu me encontrava na Europa, e lá assisti à chegada do rock que vinha da América, já ganhava uma juventude de blusões negros já semimarginalizada, e que fermentava violência reprimida. $\mathrm{O}$ rock lhe deu, senão um exutório, uma expressão, no sentido forte da palavra. E, na mesma medida em que, como movimento, é movimento partido; como palavra, palavra lascada, às vezes, apenas audível; como música, marca o triunfo da percussão, das rupturas de ritmos. Na medida que reivindica uma violência (a violência que leva a quebrar as cadeiras, no final da apresentação), trazia consigo algo de insubstituível para uma geração no vazio. Para essa geração e para a minha (que aproveitou indiretamente, através de outras, essa experiência), uma coisa é certa: depois do rock nada mais será como antes (ZUMTHOR, 2005, p. 102, grifos do autor).

Com Zumthor (2005), percebemos que o rock constitui uma música que ultrapassa os limites de sua própria arte, porque se abriga, muitas vezes, na linguagem poética dos povos primitivos, visto que o espetáculo das bandas inicia com a preparação das vestimentas, como um ritual: roupas pretas, rasgadas, cabelos longos ou espetados, maquiagem forte, pendendo para o roxo, o vermelho, o vinho e o preto. Posteriormente às vestimentas, acontece a música, com uma letra e uma instrumentação rebeldes e violentas, buscando toda a liberação de energia podada pelo cotidiano difícil. A música roqueira não é violenta somente para chocar ou divertir, e sim para libertar o corpo e a mente, fazer o ouvinte vivenciar as próprias paixões reprimidas, criar vínculos de amizade e de pertencimento a uma tribo. São essas características do rock que Zumthor (2005) chama a atenção: ele gera frutos tanto na música, quanto no comportamento, mas também na poesia, porque, ali, existe um trabalho poético, cuja palavra lascada, uma rocha bruta representa e teatraliza mundos e emoções. Desse modo, no rock, encontramos o que o crítico definiu como performance.

A performance não se refere única e exclusivamente à representação da palavra. Ela vai além, porquanto a palavra performatizada tem a capacidade de instigar o ouvinte a participar, a experimentar e a vivenciar a mensagem que está em execução. Toda poesia, segundo o crítico, possui performance; contudo a canção figura como a mais perfeita delas, já que trabalha com a voz poética do eu poético e com a voz vocalizada de quem canta: "A performance é então um 
momento de recepção: momento privilegiado, em que um enunciado é realmente recebido" (ZUMTHOR, 2007, p. 50). A união das vozes cria um espaço e um tempo exclusivos para que a mensagem da poesia seja recebida pelo ser humano, pois a performance envolve corpo e emoção, uma vez que o ouvinte ou o cantor sentem a palavra poética cantada em toda a sua capacidade de recepção, o que se entende como uma recepção plena da mensagem poética. A capacidade de recepção de uma mensagem poética que se dá pela performance acontece devido às duas vozes outrora debatidas, instante em que Zumthor (2005) diz que a voz do intérprete condiz com uma reação físico-emocional de quem canta e de quem ouve, garantindo que a mensagem seja efetivamente recebida. Dessa maneira, a canção Metal contra as nuvens (1991) apresenta uma performance poética em que o eu poético é incorporado pelo intérprete que passa a assumir a voz do outro como sua. $\mathrm{O}$ cantor executa a mensagem da poesia como sendo sua voz, algo que se nota pelas nuances do tom da voz, quando ela muda ou oscila entre uma melodia mais harmônica e menos harmônica, ou quando a tonalidade da voz do cantor pende para a suavidade ou para a brutalidade, com o uso, muitas vezes, do grito, como uma liberação de energia proveniente da revolta e da recusa com o mundo em que o eu poético vive.

Na canção Metal contra as nuvens (1991), por se tratar de uma canção roqueira, a voz do intérprete não precisa ser necessariamente a do cantor profissional, porque o ouvinte também canta, também participa e compartilha a execução da letra, tornando-se uma espécie de intérprete. Consequentemente, eu poético, intérprete e ouvinte constituem uma massa que canta e compartilha a palavra poética, sendo que a mensagem do texto é recebida plenamente, porque garante que ela desperte uma reação físico-emocional.

Como dito anteriormente, a canção fora produzida nos primeiros idos da década de noventa e lançada em 1991, coincidindo com a gestão governamental de Fernando Collor de Melo. Marcada pela corrupção, a gestão chamou a atenção principalmente pelo uso da poupança de muitos brasileiros, o que gerou descontentamento e decepção. Metal contra as nuvens (1991), de alguma forma, representa esse período, porquanto versos como "Quase acreditei na sua promessa / E o que vejo é fome e destruição" e "Existem os tolos e existe o ladrão / E há quem se alimente do que é roubo" (RUSSO, 1991) denunciam uma sociedade edificada sobre a desonestidade e o egoísmo, afinal o eu poético acreditava em promessas, possivelmente em promessas de campanhas políticas, ao passo que a realidade não mudava, mantendo-se sobre a miséria. Tal edificação não incomodava aqueles que viviam do roubo e da enganação. Em consequência, ao olharmos para a política da época e o resgate da poupança, o alimento dos políticos viria do apoderamento do dinheiro do brasileiro, como insinua o verso "E há quem se alimente do que é roubo" (RUSSO, 1991).

Outros versos que levam a acreditar que a canção representa a insatisfação do eu poético está em "Vou guardar o meu tesouro / Caso você esteja mentindo" (RUSSO, 1991), cuja metáfora "tesouro" deve fazer referência à poupança resgatada pelo governo, mas que, na canção, não ficará em instituições bancárias, nas quais o governo decida usá-lo, mas escondido, porque, se a gestão mentir, o eu poético tem a certeza de que suas posses estão seguras. Apesar da canção recriar os desapontamentos do eu poético frente a uma sociedade marcada por más

Anu. Lit., Florianópolis, v. 25, n. 2, p. 15-27, 2020. ISSNe 2175-7917 
ações, ele recria uma atitude de enfrentamento e sugere um recomeço a partir da contação das “coisas bonitas" (RUSSO, 1991). Destarte a mensagem da canção consiste na experiência e na vivência do eu poético em um mundo destronado e mau, ao mesmo tempo, insere a esperança de novos tempos.

O posicionamento do eu poético mostra - como já indicado anteriormente - uma certa individualidade em "Sou metal" (RUSSO, 1991), mas que se transporta para uma individualidade quase que coletiva, o "sou" da canção passa a ser a voz de todos, como um organismo formado de nós. A transposição é facilmente observada no último canto, quando a primeira pessoa do singular cede em definitivo à primeira pessoa do plural:

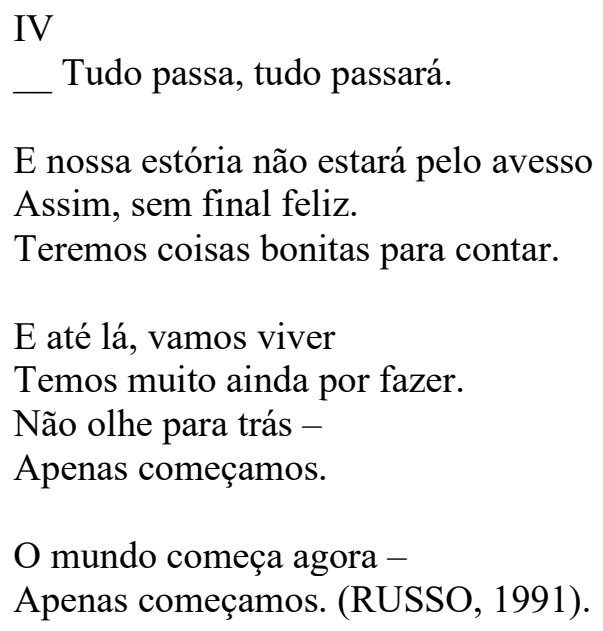

O que antes era definido por um eu individual, nas últimas estrofes, esse eu passa a se afirmar convincentemente como um nós, uma coletividade: "nossa estória", "teremos", "Temos", "começamos". A mudança de um eu individual para um nós parece ser comum nas canções de Renato Russo, talvez isso decorra porque sua poética tende a expressar o desejo da coletividade, como se o próprio eu fosse uma expressão de um todo. Ademais, essas expressões costumam sintetizar desejos e esperanças de uma sociedade, vista por Renato Russo como decadente, carente de recursos e de divisão igualitária dos bens de consumo: "É a verdade o que assombra, / O descaso o que condena, / A estupidez o que destrói” (RUSSO, 1991). Os tolos metaforizam a sociedade e o eu poético, tolos porque acreditam nos demais, os ladrões que se alimentam do que tiram do restante. Os ladrões metaforizam o sistema corrupto brasileiro. Logo a transposição do eu-indivíduo para o eu-coletivo reafirma os momentos históricos pelos quais o Brasil vivia: a crença e a decepção com o governo e o desejo de ter uma nova sociedade.

A canção Metal contra as nuvens (1991) performatiza não somente os desejos e as esperanças de um tempo utópico e/ou um real distópico por meio de uma sociedade em declínio, mas também mostra como a voz do intérprete dá vida e matéria concreta à mensagem da canção poética, enfatizando a voz do eu poético que não acontece fora de sua execução, mas durante ela, transformando o tempo sempre no tempo presente: "performance designa um ato de comunicação como tal; refere-se a um momento tomado como presente" (ZUMTHOR, 2007, 
p. 50). Em suma, como dizia Paul Zumthor (2007, p. 50), "a performance existe fora da duração", pois ela não se destina à pura recepção da palavra. Sua duração não existe, porque depende do tempo da canção que torna o tempo sempre presente, porquanto o corpo do ouvinte sente o texto no momento da execução, no instante do canto.

Ao ouvir Metal contra as nuvens (1991), a mensagem do eu poético faz-se de um tempo presente: as decepções, as esperanças, o real distópico e o sonho utópico, tudo está no instante da canção. A voz do eu poético, a voz do intérprete e a voz do ouvinte ganham nuances melodiosos, seja ganhando leveza, seja ganhando brutalidade; sendo que as nuances reforçam a atmosfera de luta e de batalha que a palavra poética da canção proporciona: "O mundo começa agora - / Apenas começamos" (RUSSO, 1991).

\section{Considerações finais}

As críticas e as teorias acerca da poesia vocalizada de Paul Zumthor (2005; 2007) exigem muito mais aprofundamento do que o artigo concede, portanto o que temos aqui é somente um vislumbre superficial. Entretanto, serve-nos para pensar que Zumthor abre caminhos para o estudo e a pesquisa da poesia que sobrevive no limite entre duas artes, a literatura e a música, afinal nem tudo o que está na música pertence ou usufrui a linguagem poética, como na literatura pouco deparamo-nos com a música. Mas, como previa Décio Pignatari (1981), a poesia constitui-se de uma linguagem livre, que circula em todas as outras e não deveria ficar confinada ao estudo da literatura.

A reflexão sobre a voz do eu poético e sobre a voz vocalizada do cantor deixa-nos a observação de que muitas canções, como as do compositor-poeta Renato Russo, fazem livre uso da palavra poética, ainda que, na atualidade, essa palavra poética não tenha origem na oralidade como os povos primitivos, e sim no domínio da escrita. À vista disso, compreender a linguagem poética que se presentifica na canção pode fazer com que a análise não seja a mesma de uma poesia basicamente escrita, sem a voz vocalizada. Assim, Metal contra as nuvens (1991) fornece a chance de verificar que o elemento sonoro da voz coaduna e fortifica as metáforas presentes no texto, permitindo que a letra de música passe a ser considerada canção poética e lembrando que a canção, segundo Paul Zumthor (1997), consiste na melhor expressão da poesia, afinal, na canção, a performance realiza-se plenamente.

\section{Referências}

JACOBY, Russel. Imagem imperfeita: pensamento utópico para uma época antiutópica. Trad. de Carolina de Melo Bomfim Araújo. Rio de Janeiro: Civilização Brasileira, 2007.

MORE, Thomas. A Utopia ou o tratado da melhor forma de governo. Trad. de Paulo Neves. Porto Alegre: L\&PM, 2015.

PAZ, Octavio. O arco e a lira. Trad. de Olga Savary. Rio de Janeiro: Nova Fronteira, 1982.

PIGNATARI, Décio. Comunicação poética. 3. ed. São Paulo: Moraes, 1981. 
RUSSO, Renato. Metal contra as nuvens. In: LEGIÃO URBANA. $V$. Manaus: EMI, 1991. 1 cd. Faixa 02 (11m 20s).

SPINA, Segismundo. Na madrugada das formas poéticas. 2. ed. Cotia: Ateliê Editorial, 2002.

ZUMTHOR, Paul. Introdução à poesia oral. Trad. de Jerusa Pires Ferreira. São Paulo: HUCITEC, 1997.

ZUMTHOR, Paul. Escritura e nomadismo. Trad. de Jerusa Pires Ferreira e Sonia Queiroz. Cotia: Ateliê Editorial, 2005.

ZUMTHOR, Paul. Performance, recepção, leitura. 2. ed. Trad. de Jerusa Pires Ferreira e Suely Fenerich. São Paulo: Cosac Naify, 2007.

\section{NOTAS DE AUTORIA}

Elisângela Maria Ozório (profelisma@gmail.com) é doutora em Letras, com área em Teoria Literária, pela UNESP de São José do Rio Preto, mestra em Literatura e Crítica Literária pela $\mathrm{PUC} / \mathrm{SP}$, graduada em Letras pelo Centro Universitário UNIFIEO. Atualmente é graduanda em Pedagogia da UNICESUMAR. Atua há vinte anos na Educação Básica do Estado de São Paulo e, nos últimos sete anos, tem se dedicado mais ao Ensino Médio e ao ensino da literatura.

\section{Como citar esse artigo de acordo com as normas da revista}

OZÓRIO, Elisângela Maria. Poesia segundo Paul Zumthor na canção Metal contra as nuvens, de Renato Russo. Anuário de Literatura, Florianópolis, v. 25, n. 2, p. 15-27, 2020.

\section{Contribuição de autoria}

Não se aplica.

\section{Financiamento}

Não se aplica.

Consentimento de uso de imagem

Não se aplica.

\section{Aprovação de comitê de ética em pesquisa}

Não se aplica.

\section{Licença de uso}

Este artigo está licenciado sob a Licença Creative Commons CC-BY. Com essa licença você pode compartilhar, adaptar, criar para qualquer fim, desde que atribua a autoria da obra.

\section{Histórico}

Recebido em: 23/03/2020

Revisões requeridas em: 10/07/2020

Aprovado em: 17/07/2020

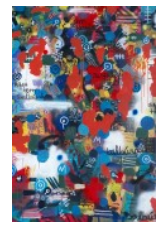

